\title{
Seniors' Physical Activity in Neighborhood Parks and Park Design Characteristics
}

\author{
Yujia Zhai ${ }^{1}$, Dongying $\mathrm{Li}^{2}$, De Wang ${ }^{1}$ and Cheng Shi ${ }^{1 *}$ \\ ${ }^{1}$ College of Architecture and Urban Planning, Tongji University, Shanghai, China, ${ }^{2}$ Department of Landscape Architecture \\ and Urban Planning, College of Architecture, Texas A\&M University, College Station, TX, United States
}

OPEN ACCESS

Edited by:

Yi Lu,

City University of Hong Kong,

Hong Kong

Reviewed by:

Levent Dalar

Istanbul Bilim University, Turkey

Gulnihal Ozbay,

Delaware State University,

United States

*Correspondence:

Cheng Shi

chengshi@tongji.edu.cn

Specialty section:

This article was submitted to

Environmental Health,

a section of the journal

Frontiers in Public Health

Received: 12 April 2020

Accepted: 12 June 2020

Published: 29 July 2020

Citation:

Zhai Y, Li D, Wang D and Shi C (2020) Seniors' Physical Activity in Neighborhood Parks and Park Design

Characteristics.

Front. Public Health 8:322.

doi: 10.3389/fpubh.2020.00322
Physical activity brings multiple health benefits to seniors. Neighborhood parks provide seniors with accessible spaces and opportunities to engage in physical activity. This study investigated the associations between neighborhood park design characteristics and seniors' total walking step and energy expenditure during the park visit. Seniors' total step was measured by pedometer, and energy expenditure was calculated based on self-reported activities in the park. The study was conducted in 15 neighborhood parks with an area $<10$ ha, and included 234 senior participants. One-way ANOVA analyses indicated that seniors in parks with larger surface area, longer trail, larger natural area and outdoor fitness equipment had taken more steps. While seniors in parks without water expended more energy. For instance, seniors in parks with surface areas $<3$ ha walked 507 fewer steps than seniors in parks with areas between 3 and 5 ha, and 691 fewer steps than those in parks larger than 5 ha. When including seniors' demographic attributes, multiple regression analyses suggested that total step was negatively associated with age, but positively associated with total natural area in the park and the presence of outdoor fitness equipment. Seniors energy expenditure was positively associated with $\mathrm{BMI}$ and the presence of outdoor fitness equipment. Energy expenditure was also related to income. These findings provide direct implications for neighborhood park design and management. Planners and designers can include more natural areas over paved areas, create longer trails and place more outdoor fitness equipment in parks to encourage seniors to walk and spend more energy.

Keywords: neighborhood park, design characteristic, senior, walking, energy expenditure, pedometer

\section{INTRODUCTION}

Physical inactivity increases the risk of various chronic diseases, e.g., diabetes, cerebrovascular diseases, and obesity, which represent leading causes of death in the senior population. Conversely, appropriate levels of activity provide multiple benefits to seniors' physical and mental health $(1,2)$. Despite these facts, it is challenging to encourage seniors to stay physically active. Providing a safe, barrier-free, and healthy built environment for activities is critical to encouraging seniors' physical activity.

Urban parks are outdoor environments that facilitate physical activity for all ages (3-6), and they are also where seniors usually choose to engage in physical activity (7). Seniors prefer natural environments than built environments more than other adults $(8,9)$. Seniors tend to be physically 
active during park visits, and spend half their time walking (10). Existing research indicates that seniors prefer neighborhood park without nuisance, with many trees and plants (11). However, the characteristics of seniors' physical activity in urban parks have not been thoroughly explored, and their needs in the urban park are not well understood $(4,12-14)$.

Existing research has examined the relationship between parks and physical activity from two directions. The first is how park characteristics relate to residents' overall physical activity at the neighborhood level, such as the amount of moderate and vigorous physical activity of residents in 1 week (3), and whether residents achieve recommended levels of activity (15). Important park characteristics that encourage physical activity at the neighborhood level are: more parks and green space (16), larger park size (6), more features in the park (17), and proximity of residents to parks $(3,4)$. These findings support the inclusion of more green space and park facilities in community planning and policy-making. The second perspective is how different park activity zones encourage moderate and vigorous physical activity at the activity zone level, such as the numbers of individuals engaging in moderate and vigorous activities on park pathways or in open spaces (18). Trails have the strongest relationship with park use for walking and other physical activities $(17,19,20)$. However, considering activity at the zone level does not allow researchers to capture an individual's total physical activity in the park. It is important to understand how park characteristics may influence physical activity at the level of individual visitors. Without this information, urban designers and green space managers lack key guidance on how to design a neighborhood park to maximize its health benefits.

Another potential limitation of existing studies is the methods by which physical activity is captured. Widely-used methods include self-reported activity and on-site observation. The selfreported approach asks participants to record their physical activity during a period, such as whether they visited the park for physical activity and which specific park facilities they used (17), and the duration of physical activity (21-23). However, these methods are susceptible to recall bias and may not accurately represent actual activity levels $(5,24)$. On-site observation tools, such as the System for Observing Play and Recreation in Communities (SOPARC), can be used to examine differences in physical activity level between various park activity zones $(25,26)$. Using this tool, researchers scan the whole activity zone at sampling moments and count the numbers of visitors engaging in physical activities with different intensities. However, scanning may not be effective in heavily-used urban parks full of people, and accurate recording is often costly and time-consuming (5). Therefore, objective approaches that can efficiently collect data on park users' physical activity are needed $(5,21)$. Equipment such as pedometers and accelerometers have been used to measure the intensity of physical activity $(5,27,28)$, but few studies have employed them to examine physical activity in urban parks.

Furthermore, few studies have addressed how park characteristics may impact physical activity from a design perspective (29). Designers are interested in knowing how many paved open spaces should be provided, how the trails should be distributed, and how large natural areas such as lawns and groves should be. However, existing findings may only suggest the presence of trail that would facilitate physical activity, rather than addressing design characteristics of these features, thus may have limited implications for park design. Therefore studies that can bear design implications and inform design practices are needed $(5,26,30,31)$.

This study aims to address the above-mentioned knowledge gaps by examining how neighborhood park design characteristics relate to seniors' walking and energy expenditure on park visit at the individual level. We used pedometers to measure seniors' total steps taken during their park visits and estimated energy expenditure based on their recall of the activities they engaged in. This study can provide empirical evidence on how neighborhood park design attributes may relate to the physical activity of seniors in parks as well as providing an approach for collecting physical activity data. Moreover, the research findings can inform future urban park design and management to promote physical activity in seniors.

\section{METHODS}

\section{Study Sites}

Neighborhood parks provide seniors with accessible outdoor spaces to engage in physical activities. Fifteen neighborhood parks in the city of Shanghai were selected as study sites (Table 1, Figure 1). Shanghai is the second-largest city in China, with an area of $\sim 6,300 \mathrm{~km}^{2}$ and a population of 24 million people at the end of 2016 (33). Its population density is very high, with 18,000 to 32,000 residents per $\mathrm{km}^{2}$ in the central districts (33). Three main ring-shaped roads (the inner ring, the middle ring and the

TABLE 1 | Selected urban parks.

\begin{tabular}{|c|c|c|c|c|c|}
\hline $\begin{array}{l}\text { Area } \\
\text { category }\end{array}$ & No. & Park name & $\begin{array}{l}\text { Area } \\
\text { (ha) }\end{array}$ & $\begin{array}{l}\text { Number of visitors in } \\
2015 \text { (32) }\end{array}$ & District \\
\hline \multirow{3}{*}{$\begin{array}{l}\text { Park area } \\
<3 \text { ha }\end{array}$} & 1 & Songhe Park & 1.6 & 712,604 & Yangpu district \\
\hline & 2 & Liyuan Park & 1.7 & 323,092 & Huangpu district \\
\hline & 3 & Huaihai Park & 2.5 & $1,942,450$ & Huangpu district \\
\hline \multirow{8}{*}{$\begin{array}{l}3 \text { ha } \leq \\
\text { Park area } \\
<5 \text { ha }\end{array}$} & 4 & Penglai Park & 3.2 & 186,016 & Huangpu district \\
\hline & 5 & Minxing Park & 3.2 & 834,982 & Yangpu district \\
\hline & 6 & Guilin Park & 3.6 & 242,040 & Xvhui district \\
\hline & 7 & Caoxi Park & 3.8 & 624,430 & Xvhui district \\
\hline & 8 & $\begin{array}{l}\text { Siping } \\
\text { Technology } \\
\text { Park }\end{array}$ & 3.8 & 398,122 & Yangpu district \\
\hline & 9 & $\begin{array}{l}\text { Douxiang } \\
\text { Park }\end{array}$ & 3.8 & 291,363 & $\begin{array}{l}\text { Pudong new } \\
\text { district }\end{array}$ \\
\hline & 10 & Jiangpu Park & 3.8 & 1,228,734 & Yangpu district \\
\hline & 11 & $\begin{array}{l}\text { Sichuan } \\
\text { North Road } \\
\text { Park }\end{array}$ & 4.5 & $10,723,216$ & Hongko district \\
\hline \multirow{4}{*}{$\begin{array}{l}5 \text { ha } \leq \\
\text { Park area } \\
<10 \text { ha }\end{array}$} & 12 & Quyang Park & 6.2 & 1,468,108 & Hongko district \\
\hline & 13 & Fuxing Park & 6.5 & $7,515,059$ & Huangpu district \\
\hline & 14 & Nan Park & 8.6 & 1,012,700 & Huangpu district \\
\hline & 15 & Xvjiahui Park & 8.9 & $12,157,350$ & Xvhui district \\
\hline
\end{tabular}


outer ring) divide Shanghai into four parts, and the 6th National Census of Population shows that population density decreases from the area within the inner ring to the area beyond the outer ring (34). The city has 165 urban parks with a total area of 24 $\mathrm{km}^{2}$ (32). Due to limited land availability, most urban parks in Shanghai have a small surface area (35); around half of them are $<5$ ha (36). Fifteen neighborhood parks with surface areas of between 3 ha and 10 ha were selected as study sites based on the following criteria: 1 . the park administrators approved data collection; 2. detailed digital survey documents of the park were obtainable; and 3 . the park served the general public and was open to all. The 15 neighborhood parks all have common activity zones, such as lawns, trails, and paved open spaces (Figure 2). All parks are either within or very close to the middle ring and are frequently used by the citizens. Annual visitor numbers from 2015 for the selected parks ranged from 186,016 to $12,157,350$.

\section{Procedure}

The study was conducted on sunny or cloudy weekdays during 3 weeks in October of 2017, when the weather in Shanghai is conducive to outdoor activities. Sampling days consisted of two data collection sessions, one in the morning (9:00 am-12:00 $\mathrm{pm})$ and one in the afternoon (1:00 pm-5:00 pm). Researchers were stationed at the most frequently-used park entrance and invited seniors entering the park to voluntarily participate in the study. Three criteria were used in screening participants: 1 . The participant should be aged 60 and above, 2 . The participant did not need walking aids, and 3. The participant planned to visit the park, rather than pass through. Once a senior park user agreed to participate in the study, he or she was asked to sign a consent form and provided with the researcher's telephone number. The participant's telephone number was also recorded with their approval.

When distributing pedometers, the researcher turned on the pedometer and made sure it had been reset, and helped the participant put it around their neck or on their waist, where pedometer has a high reliability (37). We also instructed the participant not to touch the buttons on pedometers to prevent them from turning it off or resetting the record by accident. When pedometers were returned, the researcher recorded the total steps measured, as well as the time of return

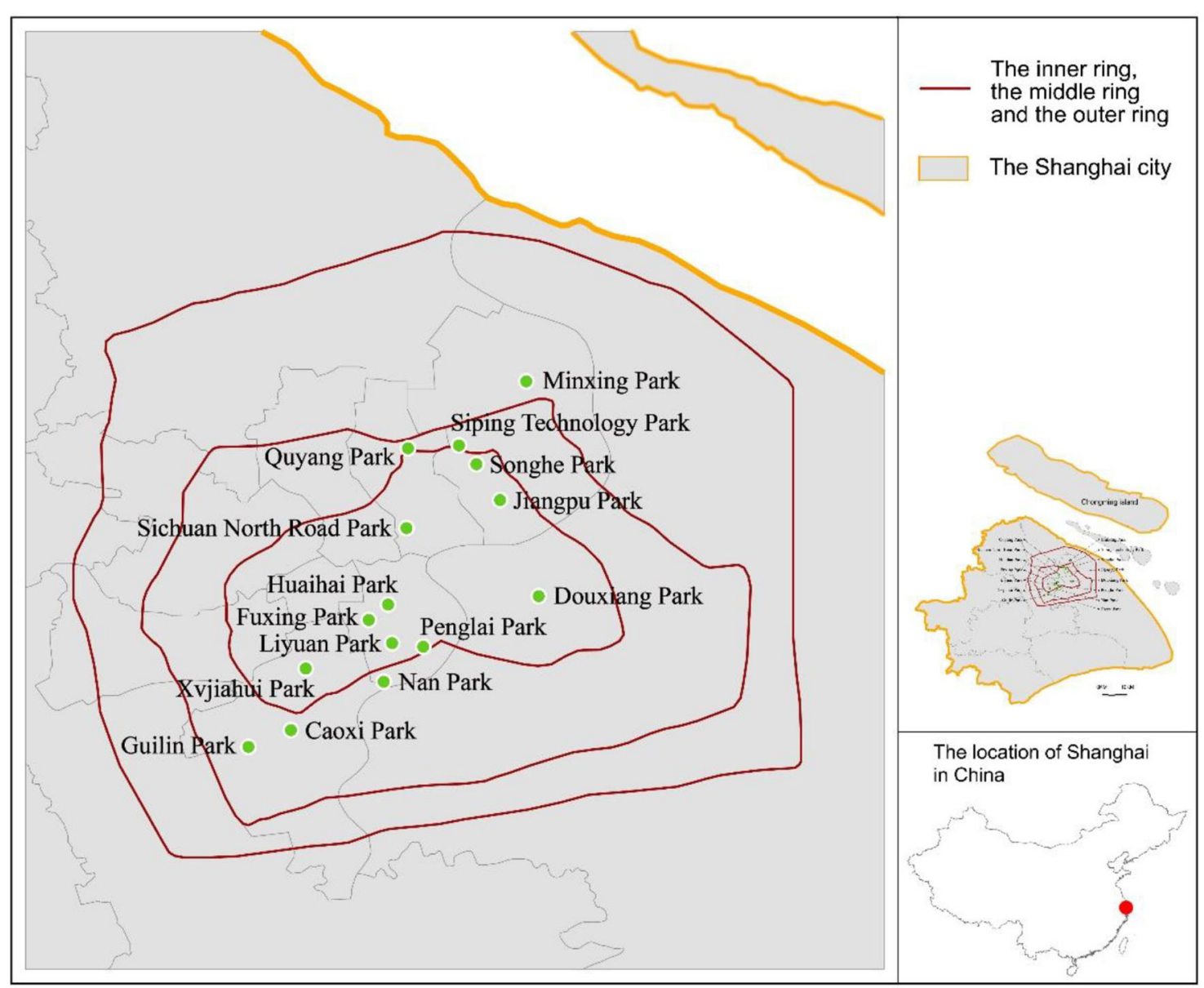

FIGURE 1 | Locations of the 15 neighborhood parks in Shanghai. 

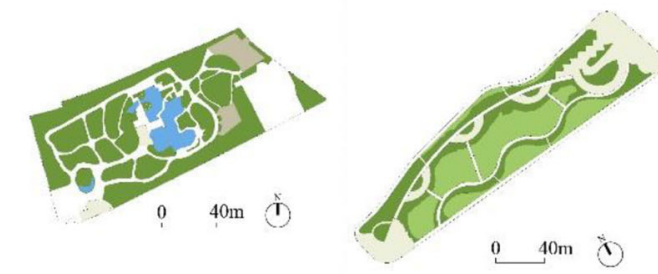

Songhe Park
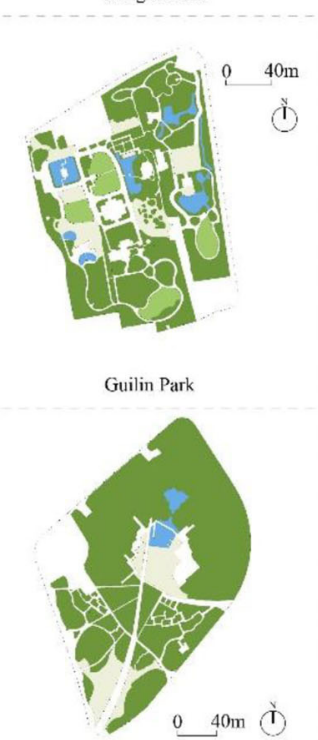

Sichuan Norih Road Park

Liyuan Park

Caoxi Park

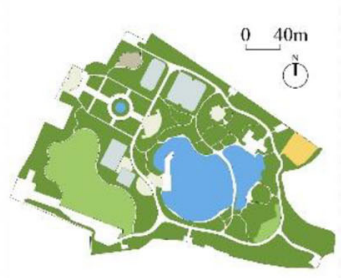

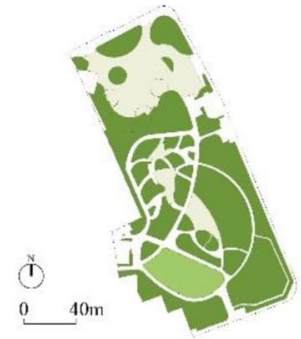

Iluaihai Park

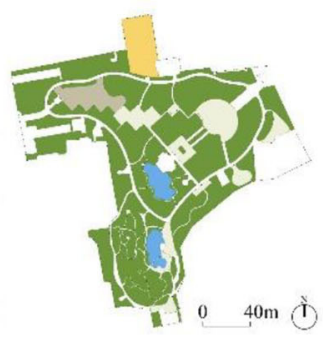

Penglai Park

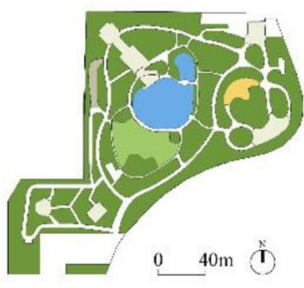

Minxing Park
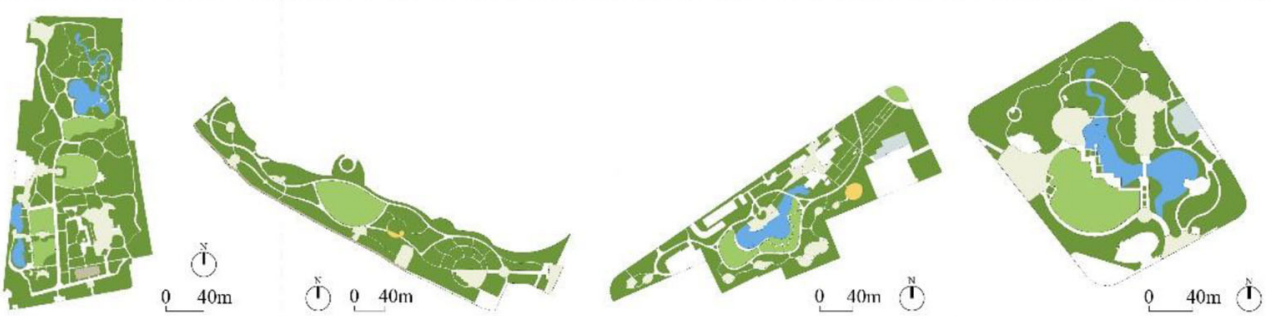

Siping Technology Park

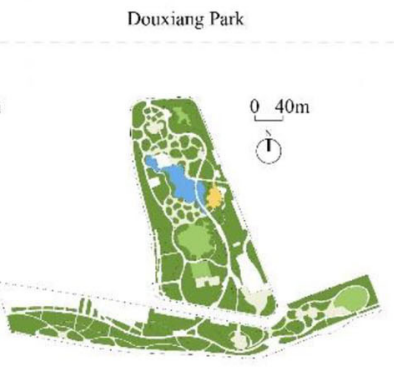

Jiangpu Park

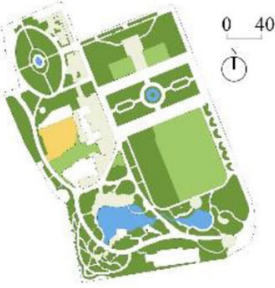

Fuxing Park

Nan Park

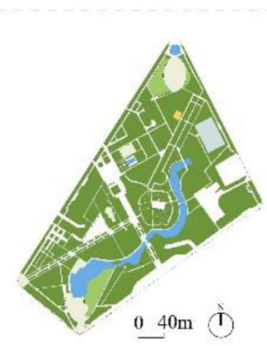

Xvjiahui Park

FIGURE 2 | Master Plans of the 15 neighborhood parks. [Figure credit: authors; an adapted version of figure has been published in article that belong to the same project (13).]

in order to discriminate step data from different participants. At the time of return, participants were invited to complete a questionnaire addressing their demographic information, daily park use patterns, and physical activities in the park. We asked participants to recall and report in chronological order each activity they engaged in and the duration of each activity.

\section{Measures}

\section{Total Steps and Energy Expenditure in Parks}

The physical activity of senior park users was assessed using the total steps measured by pedometer and by self-reported energy expenditure. The pedometer used in this study was the Yamax Power Walker EX-510 (Yamax Corp., Tokyo, Japan), which showed a high accuracy in counting steps (37). Existing research has proven the validity of pedometer in measuring physical activity $(27,28)$. In particular, the Yamax pedometer has been shown to be very accurate in recording steps and distance (38), and in counting the steps of seniors who neither uses walking aids nor walk very slow (39). Specifically, when walking speed is $>0.83$ $\mathrm{m} / \mathrm{s}$, its step counts have acceptable error rates (40). Typically, seniors aged 60 and above have a walking speed $>1 \mathrm{~m} / \mathrm{s}(41)$, thus it is appropriate to measure their steps with a pedometer.

Energy expenditure was calculated based on participants' reported activity types and durations. Using the Compendium for Physical Activities, we identified the metabolic equivalent (MET) intensity level for each type of activity reported by participants. The MET is a standardized measure of activity intensity defined as the ratio of work to resting metabolic rate. For example, walking is estimated as 3 METs and running is considered to be 6 METs. We calculated the energy expenditure of each participant for each activity by multiplying their weight $(\mathrm{kg})$, the energy cost (METs) of a given physical activity $\left(\mathrm{kcal} \cdot \mathrm{kg}^{-1} \cdot \mathrm{h}^{-1}\right)$, and the duration of the physical activity $(\mathrm{h})$.

\section{Park Design Characteristics}

We measured seven park design characteristics: 1. Park area, 2. Total trail length, 3 . Total paved activity zone area, 4 . Total natural area, 5. Presence of water, 6. Presence of outdoor fitness equipment, and 7. Presence of court (Figure 3). Table 2 provides the definition, justification, type, and data source for these design characteristics. We hypothesized that parks 


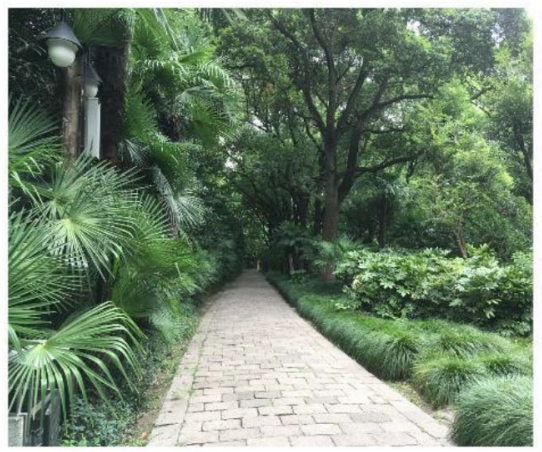

Trail

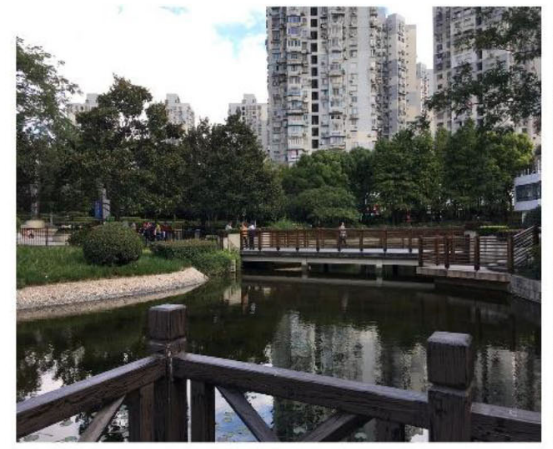

Water

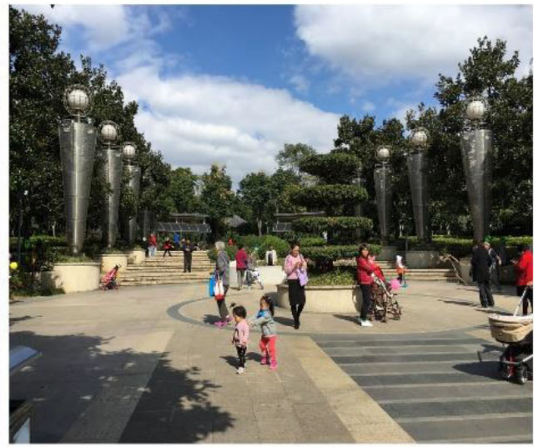

Paved activity zone

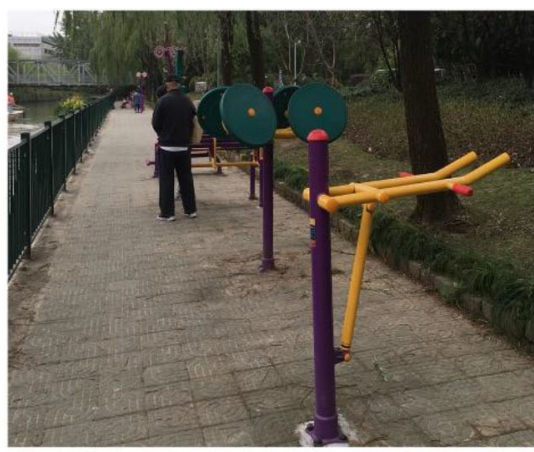

Outdoor fitness equipment

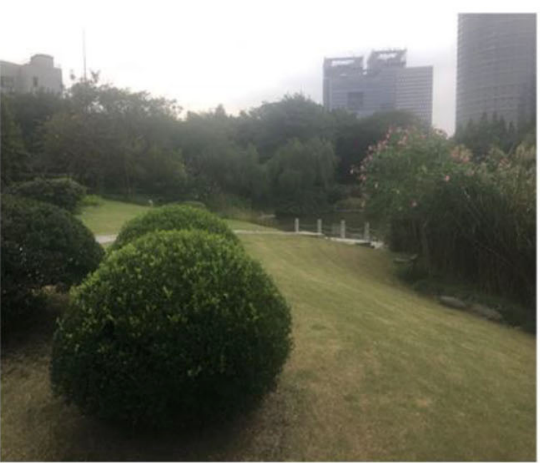

Natural area

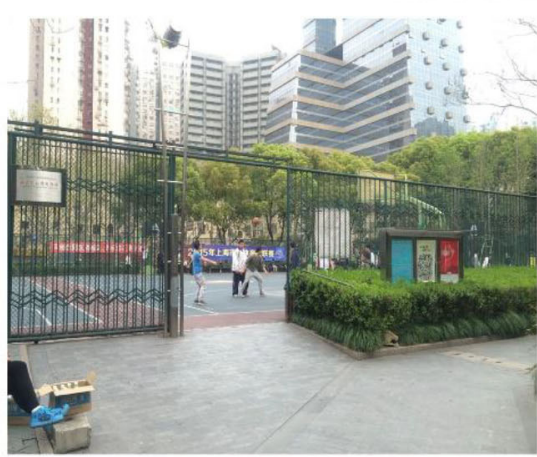

Court

FIGURE 3 | Park scenes of the study parks.

with larger areas, more trails, larger paved activity zone area, larger natural area, water features, outdoor fitness equipment, and courts would be associated with more steps and more energy expenditure for senior users. All design variables were measured based on surveys of parks in AutoCAD format provided by the Shanghai Greening Administration Bureau and local park administrators. The researchers visited all 15 parks, field-validated the survey drawings, corrected errors, identified activity zone types, and then calculated values for each park's design characteristic variables using AutoCAD (Figure 4).

\section{Statistical Analyses}

Statistical Analyses were conducted using IBM SPSS Statistics. Descriptive statistics were used to determine general characteristics of the collected sample data and park design characteristics. One-way ANOVA tests were then fitted to test whether seniors' physical activity, including total steps and energy expenditure, differed between parks with different design characteristics. In ANOVA analysis, park design characteristics were coded as categorical variables (Table 2). Park area was classified as smaller than 3 ha, 3-5 ha, and larger than 5 ha; trail length as $<1 \mathrm{~km}, 1-2 \mathrm{~km}$, and longer than $2 \mathrm{~km}$; paved activity zone areas as $<0.4$ ha, $0.4-0.6$ ha, and larger than $0.6 \mathrm{ha}$; and natural area as $<2$ ha, 2-4 ha, and larger than 4 ha.
We then used regression models to examine the relationships between park design characteristics and seniors' walking step and energy expenditure. In the analyses, variables of park area, total trail length, total paved activity zone area and total natural area were coded as continuous variables, other park design variables, including presence of water, presence of outdoor fitness equipment, and presence of court were coded as categorical variables. First, we examined whether our data demonstrated a multi-level structure (i.e., park participants nested within parks). If so, mixed models would be required for analysis. However, when we calculated the intra-class correlation coefficient, we found the between-cluster variance to be very small (ICC $=0.050$ for total steps and ICC $=0.038$ for energy expenditure); this ruled out any need for a mixed model. We fitted linear regression models to predict total steps and energy expenditure using park design characteristics and included seniors' demographic attributes as control variables. Total steps and energy expenditure were log-transformed, as they displayed right-skewed distributions. Since park design characteristic variables exhibited collinearity, stepwise models selection were applied for the both models.

\section{RESULTS}

\section{Descriptive Statistics}

Total of 257 senior park users participated in the study (Table 3). Those who returned with the pedometer turned 
TABLE 2 | Seniors' physical activity variables and neighborhood park design variables.

\begin{tabular}{|c|c|c|c|c|}
\hline & Definition/measurement & Justification & Variable type & Data source \\
\hline \multicolumn{5}{|l|}{ Seniors' physical activity variables } \\
\hline 1. Total step & $\begin{array}{l}\text { Total steps seniors } \\
\text { walked during the park } \\
\text { visit }\end{array}$ & - & Continuous & Pedometer \\
\hline 2. Energy expenditure & $\begin{array}{l}\text { Total energy senior } \\
\text { expended during the } \\
\text { park visit }\end{array}$ & - & Continuous & $\begin{array}{l}\text { Questionnaire/ } \\
\text { calculated based on } \\
\text { compendium of } \\
\text { Physical Activities }\end{array}$ \\
\hline \multicolumn{5}{|l|}{ Neighborhood park design variables } \\
\hline 1. Park area & $\begin{array}{l}\text { Surface area of the } \\
\text { entire park }\end{array}$ & $\begin{array}{l}\text { Large parks tend to have } \\
\text { more features (42), which may } \\
\text { encourage more physical } \\
\text { activities. }\end{array}$ & $\begin{array}{l}\text { Categorical }(<3 \\
\text { ha, } 3-5 \text { ha and } \geq 5 \\
\text { ha)/Continuous }\end{array}$ & $\begin{array}{l}\text { Park AutoCAD } \\
\text { map/site visit }\end{array}$ \\
\hline 2. Total trail length & $\begin{array}{l}\text { Total length of all trails in } \\
\text { the park }\end{array}$ & $\begin{array}{l}\text { Parks with a track appeared } \\
\text { to draw more seniors (4). }\end{array}$ & $\begin{array}{l}\text { Categorical } \\
(<1 \mathrm{~km}, 1-2 \mathrm{~km} \\
\text { and } \\
\geq 2 \mathrm{~km}) / \text { Continuous }\end{array}$ & $\begin{array}{l}\text { Park AutoCAD map } \\
\text { /site visit }\end{array}$ \\
\hline $\begin{array}{l}\text { 3. Total paved activity } \\
\text { zone area }\end{array}$ & $\begin{array}{l}\text { The total area of all } \\
\text { paved activity zones in } \\
\text { the park, e.g., open } \\
\text { space, court and paved } \\
\text { children playground. }\end{array}$ & $\begin{array}{l}\text { Larger activity zone appeared } \\
\text { to attract more users (43). }\end{array}$ & $\begin{array}{l}\text { Categorical }(<0.4 \\
\text { ha, } 0.4-0.6 \text { ha } \\
\text { and, } \geq 0.6 \\
\text { ha)/Continuous }\end{array}$ & $\begin{array}{l}\text { Park AutoCAD map } \\
\text { /site visit }\end{array}$ \\
\hline 4. Total natural area & $\begin{array}{l}\text { Area of natural } \\
\text { elements, e.g., water, } \\
\text { lawn, grove. }\end{array}$ & $\begin{array}{l}\text { Nature experience could } \\
\text { benefit mental health }(44,45) \text {. } \\
\text { Adolescents exposed to more } \\
\text { nature have a better daily } \\
\text { mood (46). }\end{array}$ & $\begin{array}{l}\text { Categorical }(<2 \\
\text { ha, } 2-4 \text { ha and, } \\
\geq 4 \text { ha)/Continuous }\end{array}$ & $\begin{array}{l}\text { Park AutoCAD map } \\
\text { /site visit }\end{array}$ \\
\hline 5. Presence of water & $\begin{array}{l}\text { Presence of water in the } \\
\text { park }\end{array}$ & $\begin{array}{l}\text { Water contributes to a better } \\
\text { mood }(47,48) \text {. }\end{array}$ & $\begin{array}{l}\text { Categorical }(0= \\
\text { without, } 1=\text { with })\end{array}$ & $\begin{array}{l}\text { Park AutoCAD map } \\
\text { /site visit }\end{array}$ \\
\hline $\begin{array}{l}\text { 6. Presence of } \\
\text { outdoor fitness } \\
\text { equipment }\end{array}$ & $\begin{array}{l}\text { Presence of fitness } \\
\text { equipment in the park }\end{array}$ & $\begin{array}{l}\text { Outdoor fitness equipment } \\
\text { attracts a lot of senior users } \\
(49,50) \text { and contributes to the } \\
\text { increase of moderate and } \\
\text { vigorous physical activity }(51) \text {. }\end{array}$ & $\begin{array}{l}\text { Categorical }(0= \\
\text { without, } 1=\text { with })\end{array}$ & $\begin{array}{l}\text { Park AutoCAD map } \\
\text { /site visit }\end{array}$ \\
\hline 7. Presence of Court & $\begin{array}{l}\text { Presence of court in the } \\
\text { park }\end{array}$ & $\begin{array}{l}\text { Use of courts facilitates } \\
\text { physical activity in the park } \\
(4,18,52)\end{array}$ & $\begin{array}{l}\text { Categorical }(0= \\
\text { without, } 1=\text { with })\end{array}$ & $\begin{array}{l}\text { Park AutoCAD map } \\
\text { /site visit }\end{array}$ \\
\hline
\end{tabular}

off, or whose survey results were inconsistent with activity durations recorded on the pedometer, were excluded from the study. A total of 234 (91.05\%) participants had valid pedometer data and demographic information and were included in the analysis. On average, each park had 16 valid senior participants $(\operatorname{Min}=11, \operatorname{Max}=23, S D=3.54)$. As indicated in Table 3, the average age of participants was around 70 years old $($ Min $=60$, Max $=93, S D=7.54)$ and the average BMI of participants was 23.45 ( $\mathrm{Min}=12.37$, Max $=31.25, S D=2.89$ ). One hundred and thirty-two $(56.4 \%)$ participants were male, $188(80.3 \%)$ lived with their spouse, and $112(47.9 \%)$ had a household monthly income between 5,000 and 10,000 CNY (749-1498 USD). Eighty-six (36.8\%) seniors reported that their health was excellent or good, and $132(56.4 \%)$ seniors felt their health was fair. One hundred and sixty-seven $(71.4 \%)$ participants claimed that they came to the park for exercise, and $51(21.8 \%)$ said they came with multiple purposes.
Out of all 234 participants with valid data, 191 recalled the types of physical activity they engaged in and the duration of each type of physical activity. On average, each participant walked 2,278 steps in the park $(\operatorname{Min}=158, \operatorname{Max}=10,320, S D=$ $1,642.403)$. Of these 191 participants, one $(0.52 \%)$ engaged in four types of physical activities; 11 (5.76\%) engaged in three kinds of physical activities; 82 (42.93\%) took parts in two kinds of physical activities; and 97 (50.79\%) participated in only one type of physical activity. In total, participants reported 27 types of physical activities, the most frequently mentioned of which were walking (139 seniors, $72.77 \%$ ), meeting and chatting with friends ( 29 seniors, $15.18 \%$ ), and using outdoor fitness equipment (20 seniors, 10.47\%). We calculated the energy expenditure of each participant for each activity by multiplying their weight $(\mathrm{kg})$, the energy cost of a given physical activity $\left(\mathrm{kcal} \cdot \mathrm{kg}^{-1} \cdot \mathrm{h}^{-1}\right)$, and the duration of the physical activity $\left(\mathrm{h}^{-1}\right)$. The total energy expenditure of a participant was then calculated as the sum of energy expenditures across all kinds of activities they performed. 


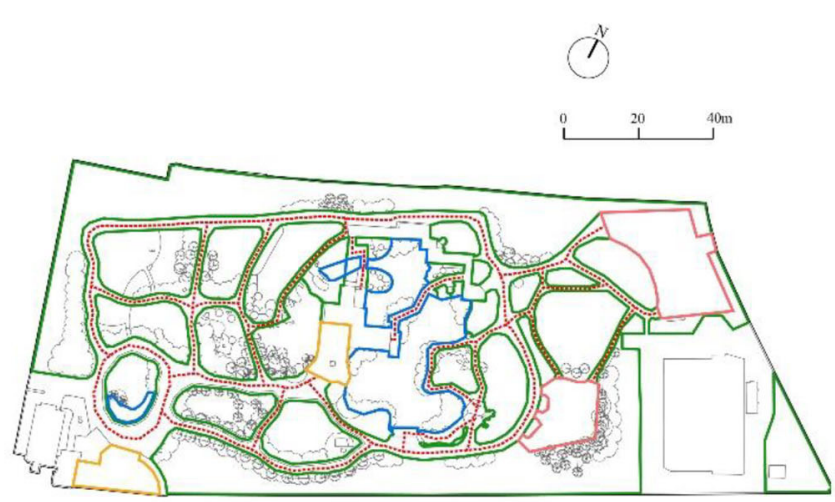

........ Trail $\square$ Paved open space

Outdoor fitness equipment

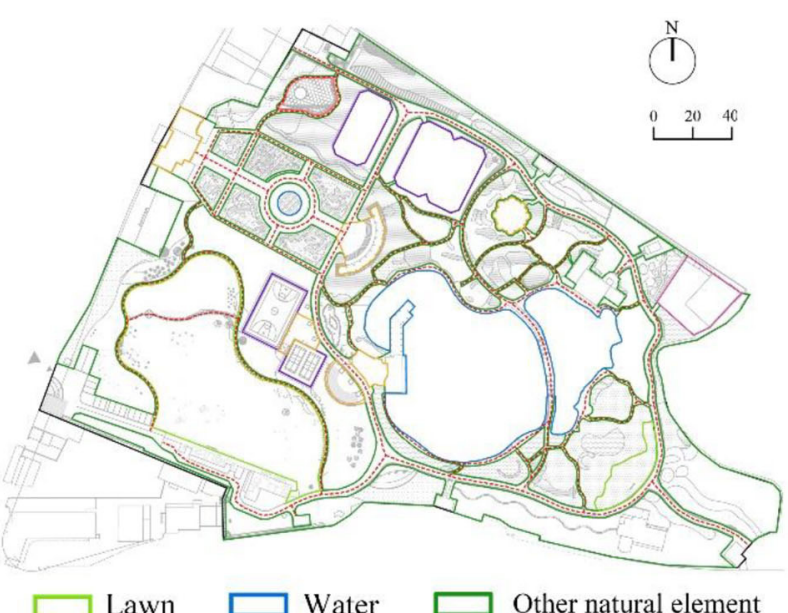

Lawn $\square$ Water
Other natural element

FIGURE 4 | Park activity zone type identification of Songhe Park (left) and Quyang Park (right).

TABLE 3 | Descriptive statistics for senior participants.

\begin{tabular}{|c|c|c|c|c|}
\hline & Minimum & Maximum & Mean & Std. deviation \\
\hline 1. Age & 60.00 & 93.00 & 69.52 & 7.540 \\
\hline 2. Height (m) & 1.48 & 1.84 & 1.64 & 0.075 \\
\hline 3. Weight (km) & 30.50 & 90.00 & 63.54 & 9.859 \\
\hline \multirow[t]{2}{*}{ 4. BMI } & 12.37 & 31.25 & 23.45 & 2.894 \\
\hline & & Frequency & Percent & \\
\hline \multirow[t]{2}{*}{ 5.Gender } & Male & 132 & 56.4 & \\
\hline & Female & 102 & 43.6 & \\
\hline \multirow[t]{2}{*}{ 6. Marital status } & Single & 46 & 19.7 & \\
\hline & Not single & 188 & 80.3 & \\
\hline \multirow{4}{*}{$\begin{array}{l}\text { 7. Houshold monthly } \\
\text { income (CNY) }\end{array}$} & $<3,000$ & 31 & 13.2 & \\
\hline & $3,000-5,000$ & 65 & 27.8 & \\
\hline & $5,000-10,000$ & 112 & 47.9 & \\
\hline & $10,000-20,000$ & 26 & 11.1 & \\
\hline \multirow{4}{*}{$\begin{array}{l}\text { 8. Self-reported } \\
\text { health condition }\end{array}$} & Excellent & 38 & 16.2 & \\
\hline & Good & 48 & 20.5 & \\
\hline & Fair & 132 & 56.4 & \\
\hline & Bad & 16 & 6.8 & \\
\hline \multirow[t]{4}{*}{ 9.Park visit purpose } & Exercise & 167 & 71.4 & \\
\hline & Contact with nature & 14 & 6.0 & \\
\hline & Meet friends & 2 & 0.9 & \\
\hline & Multiple & 51 & 21.8 & \\
\hline
\end{tabular}

On average, each senior expended 148.27 kcal ( $\mathrm{Min}=14.50$, Max $=1007.40, S D=113.579)$ during their stay in the park.

\section{Park Design Characteristics}

Table 4 reports descriptive statistics for park design characteristics. On average, the 15 neighborhood parks had a surface area of 4.4 ha $(\operatorname{Min}=1.61, \operatorname{Max}=8.92, S D=2.219)$, a total trail length of $2.27 \mathrm{~km}(\operatorname{Min}=0.533, \operatorname{Max}=6.05, S D=$
1.339), a total paved activity area of 0.49 ha $(\operatorname{Min}=0.12, \operatorname{Max}$ $=0.86, S D=0.204)$, and a total natural area of 2.68 ha $(\mathrm{Min}=$ $0.96, \operatorname{Max}=5.00, S D=1.218)$. Twelve parks $(80 \%)$ had water features, six parks (40\%) had outdoor fitness equipment, and four parks $(26.7 \%)$ contained courts. Correlation analyses were used to detect associations between park design characteristics (Table 5). The results indicated that park area was positively associated with trail length, $r(14)=0.888, p<0.001$, total paved activity zone area, $r(14)=0.660, p<0.005$, and total natural area, $r(14)=0.962, p<0.001$. Parks with larger natural area also have longer trails $r(14)=0.858, p<0.001$, and larger total paved activity zone area, $r(14)=0.588, p<0.005$. Parks with courts also tend to have larger paved activity zone area, $r(14)=$ $0.523, p<0.005$.

\section{Does Seniors' Total Step and Energy Expenditure Differ in Parks With Different Design Characteristics?}

ANOVA analyses were performed to detect the differences in seniors' mean total step and mean energy expenditure in parks with different design characteristics. The results indicated that on average, seniors walk more steps in parks with larger surface area, $F_{(2,231)}=2.45, p=0.089$, longer trail, $F_{(2,231)}=2.85, p=$ 0.060 , larger natural area, $F_{(2,231)}=6.27, p=0.002$, and outdoor fitness equipment, $F_{(1,231)}=4.00, p=0.047$ (Table 6, Figure 5). In particular, ANOVA post hoc (LSD) analyses indicated that senior participants in parks with $<3$ ha total area walked 507 fewer steps than those in parks with areas between 3 and 5 ha $(p=0.074)$, and 691 fewer steps compared to seniors in parks larger than 5 ha $(p=0.032)$ (Table 7$)$. On average, seniors in parks with more than $2 \mathrm{~km}$ of trails walked 739 more steps ( $p$ $=0.021$ ) than seniors in parks with $<1 \mathrm{~km}$ of trails. Similarly, seniors in parks with $<2$ ha of natural area walked 724 fewer steps than those in parks with between 2 and 4 ha of natural area $(p=0.003)$, and 946 fewer steps $(p=0.002)$ than those in 
TABLE 4 | Descriptive statistics for park design characteristics.

\begin{tabular}{|c|c|c|c|c|c|}
\hline & $N$ & Minimum & Maximum & Mean & Std. deviation \\
\hline Park area $\left(m^{2}\right)$ & 15 & 16058.52 & 89172.96 & 44045.893 & 22192.869 \\
\hline Total trail length (m) & 15 & 533.27 & 6048.12 & 2268.229 & 1339.746 \\
\hline Total paved activity zone area $\left(\mathrm{m}^{2}\right)$ & 15 & 1176.88 & 8589.45 & 4925.184 & 2048.820 \\
\hline \multirow[t]{2}{*}{ Total natural area $\left(\mathrm{m}^{2}\right)$} & 15 & 9613.77 & 50033.88 & 26764.212 & 12176.843 \\
\hline & & Frequency & Percent & & \\
\hline \multirow[t]{2}{*}{ Presence of water } & No water & 12 & 80.0 & & \\
\hline & With water & 3 & 20.0 & & \\
\hline \multirow[t]{2}{*}{ Presence of outdoor fitness equipment } & No fitness equipment & 6 & 40.0 & & \\
\hline & With outdoor fitness equipment & 9 & 60.0 & & \\
\hline \multirow[t]{2}{*}{ Presence of court } & No court & 4 & 26.7 & & \\
\hline & With court & 11 & 73.3 & & \\
\hline
\end{tabular}

TABLE 5 | Correlation matrix for park design characteristic variables.

\begin{tabular}{|c|c|c|c|c|c|c|}
\hline & Park area & $\begin{array}{l}\text { Total trail } \\
\text { length }\end{array}$ & $\begin{array}{l}\text { Total paved } \\
\text { activity zone } \\
\text { area }\end{array}$ & $\begin{array}{c}\text { Total natural } \\
\text { area }\end{array}$ & $\begin{array}{c}\text { Presence of } \\
\text { water }\end{array}$ & $\begin{array}{c}\text { Presence of } \\
\text { outdoor } \\
\text { fitness } \\
\text { equipment }\end{array}$ \\
\hline Total trail length ${ }^{p}$ & $0.888^{\star \star}$ & & & & & \\
\hline Total paved activity zone area ${ }^{p}$ & $0.660^{\star *}$ & 0.454 & & & & \\
\hline Total natural area ${ }^{p}$ & $0.962^{\star \star}$ & $0.858^{\star \star}$ & $0.588^{\star \star}$ & & & \\
\hline Presence of waters & 0.424 & 0.463 & 0.116 & 0.386 & & \\
\hline Presence of outdoor fitness equipment ${ }^{S}$ & -0.346 & -0.157 & -0.409 & -0.157 & 0.068 & \\
\hline Presence of Court ${ }^{\mathrm{S}}$ & 0.489 & 0.209 & $0.523^{\star \star}$ & 0.384 & 0.302 & -0.185 \\
\hline
\end{tabular}

${ }^{p}$ Pearson correlation coefficients; ${ }^{s}$ Spearman correlation coefficients.

${ }^{\star *} p<0.05$ (2-tailed).

TABLE 6 | ANOVA analysis for seniors' total step, energy expenditure and park design characteristics.

\begin{tabular}{|c|c|c|c|c|c|c|c|}
\hline & & \multicolumn{6}{|c|}{ Steps } \\
\hline & & Sum of squares & df & Mean square & $\boldsymbol{F}$ & Sig. & Sum of squares \\
\hline \multirow[t]{3}{*}{ Park area } & Between groups & 13055887.570 & 2 & 6527943.785 & 2.450 & $0.089^{\star}$ & 18761.540 \\
\hline & Within groups & 615458633.300 & 231 & 2664323.088 & & & 2432275.131 \\
\hline & Total & 628514520.900 & 233 & & & & 2451036.671 \\
\hline \multirow[t]{3}{*}{ Total trail length } & Between groups & 15140996.130 & 2 & 7570498.067 & 2.851 & $0.060^{\star}$ & 28385.552 \\
\hline & Within groups & 613373524.800 & 231 & 2655296.644 & & & 2422651.119 \\
\hline & Total & 628514520.900 & 233 & & & & 2451036.671 \\
\hline \multirow[t]{3}{*}{ Total paved activity zone } & Between groups & 4417467.558 & 2 & 2208733.779 & 0.818 & 0.443 & 19517.993 \\
\hline & Within groups & 624097053.300 & 231 & 2701718.846 & & & 2431518.678 \\
\hline & Total & 628514520.900 & 233 & & & & 2451036.671 \\
\hline \multirow[t]{3}{*}{ Total natural area } & Between groups & 32350036.860 & 2 & 16175018.430 & 6.267 & $0.002^{\star *}$ & 3074.281 \\
\hline & Within groups & 596164484.000 & 231 & 2580798.632 & & & 2447962.390 \\
\hline & Total & 628514520.900 & 233 & & & & 2451036.671 \\
\hline \multirow[t]{3}{*}{ Presence of water } & Between groups & 30279.745 & 1 & 30279.745 & 0.011 & 0.916 & 70633.114 \\
\hline & Within groups & 628484241.200 & 232 & 2708983.798 & & & 2380403.557 \\
\hline & Total & 628514520.900 & 233 & & & & 2451036.671 \\
\hline \multirow[t]{3}{*}{ Presence of outdoor fitness equipment } & Between groups & 10642189.750 & 1 & 10642189.750 & 3.996 & $0.047^{\star \star}$ & 13934.383 \\
\hline & Within groups & 617872331.200 & 232 & 2663242.807 & & & 2437102.288 \\
\hline & Total & 628514520.900 & 233 & & & & 2451036.671 \\
\hline \multirow[t]{3}{*}{ Presence of court } & Between groups & 3754170.004 & 1 & 3754170.004 & 1.394 & 0.239 & 181.134 \\
\hline & Within groups & 624760350.900 & 232 & 2692932.547 & & & 2450855.537 \\
\hline & Total & 628514520.900 & 233 & & & & 2451036.671 \\
\hline
\end{tabular}

${ }^{*} p<0.10$ (2-tailed). ${ }^{* *} p<0.05$ (2-tailed). 

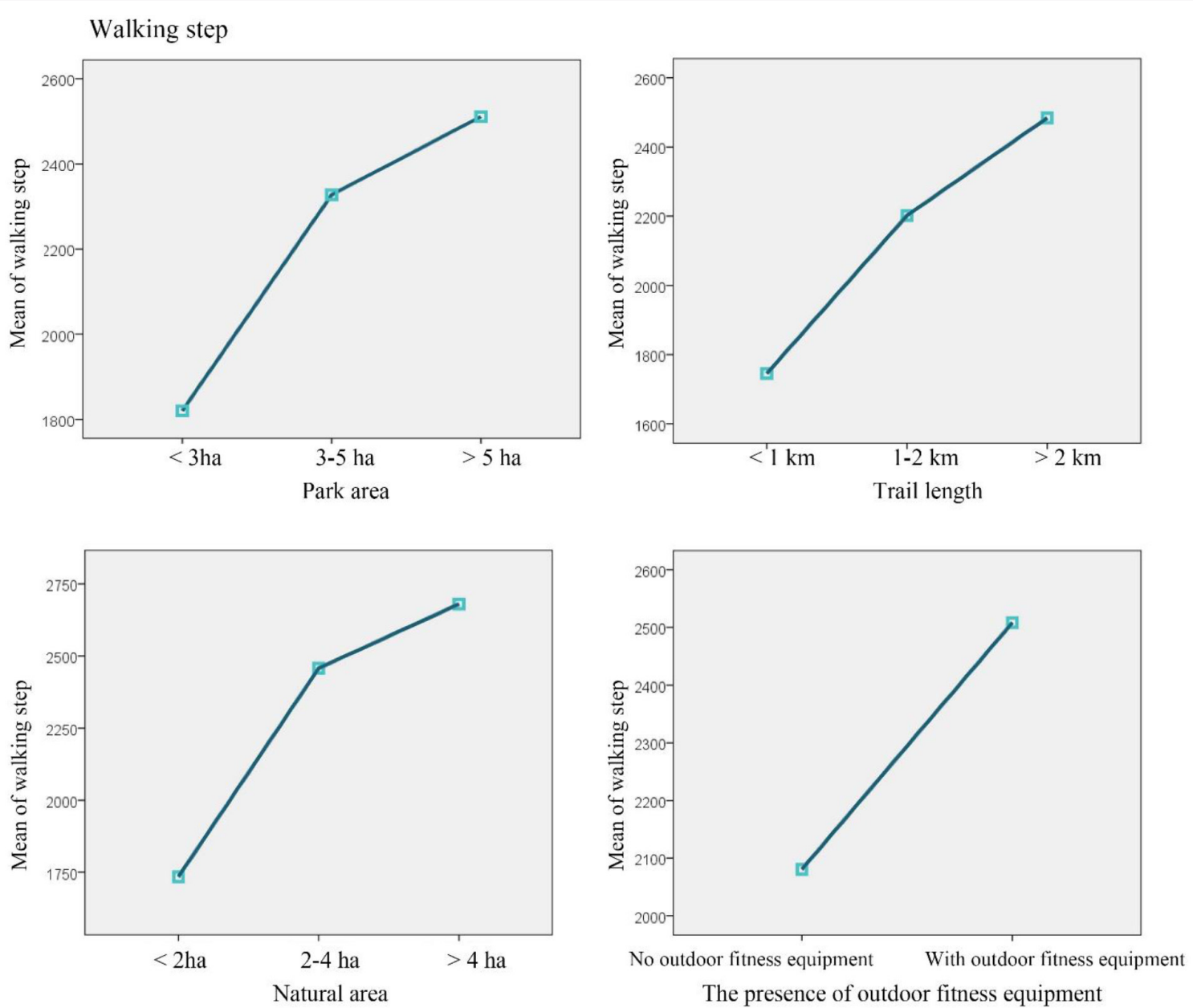

Energy expenditure

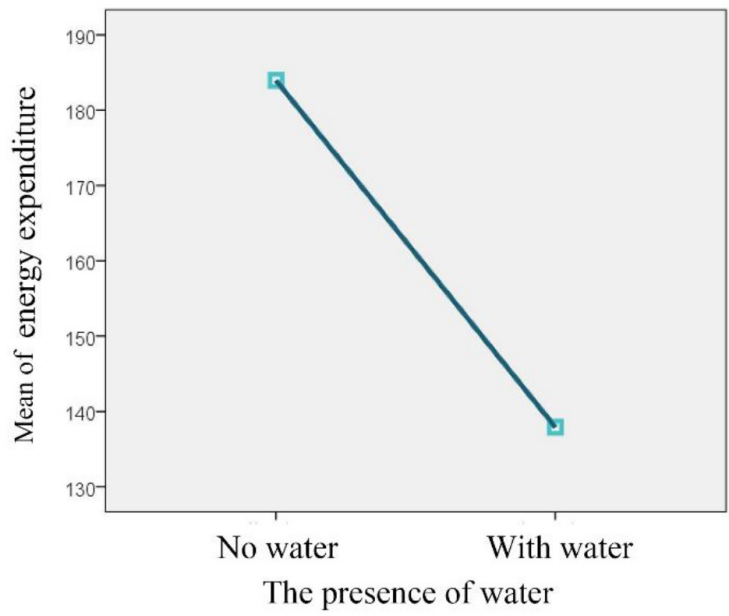

FIGURE 5 | Differences in seniors' total walking step and energy expenditure in parks with different design characteristics.

parks with more than 4 ha of natural area. Seniors expended more energy in parks without water, $F_{(1,189)}=5.608, p=0.019$, but no significant differences in seniors' average energy expenditure were detected between parks with different sizes, $F_{(2,188)}=.725$, $p=0.486$, trail lengths, $F_{(2,188)}=1.101, p=0.335$, paved activity zone areas, $F_{(2,188)}=0.755, p=0.472$, natural areas, $F_{(2,188)}$ 
TABLE 7 | AOVA post hoc (LSD) analysis for total step and neighborhood park design characteristics.

\begin{tabular}{|c|c|c|c|c|c|}
\hline & (I) & (J) & $\begin{array}{l}\text { Mean } \\
\text { difference } \\
\text { (I-J) }\end{array}$ & Std. error & Sig. \\
\hline \multirow[t]{3}{*}{ Park area } & $<3$ ha & 3-5 ha & -507.255 & 282.882 & $0.074^{\star}$ \\
\hline & & $\geq 5$ ha & -690.803 & 320.756 & $0.032^{\star \star}$ \\
\hline & $3-5$ ha & $\geq 5$ ha & -183.548 & 253.954 & 0.471 \\
\hline \multirow[t]{3}{*}{ Trail length } & $<1 \mathrm{~km}$ & $1-2 \mathrm{~km}$ & -456.819 & 332.383 & 0.171 \\
\hline & & $\geq 2 \mathrm{~km}$ & -738.972 & 317.174 & $0.021^{\star \star}$ \\
\hline & $1-2 \mathrm{~km}$ & $\geq 2 \mathrm{~km}$ & -282.154 & 234.274 & 0.230 \\
\hline \multirow[t]{3}{*}{ Natural area } & $<2$ ha & 2-4 ha & -723.567 & 240.629 & $0.003^{\star \star}$ \\
\hline & & $\geq 4$ ha & -945.942 & 305.279 & $0.002^{\star \star}$ \\
\hline & 2-4 ha & $\geq 4$ ha & -222.374 & 281.796 & 0.431 \\
\hline
\end{tabular}

${ }^{*} p<0.10$ (2-tailed). ${ }^{\star \star} p<0.05$ (2-tailed).

$=0.188, p=0.889$, presence of outdoor fitness equipment, $F_{(1,189)}=1.081, p=0.300$, or presence of court, $F_{(1,189)}=0.014$, $p=0.906$.

\section{Do Relationships Between Seniors' Total Step and Energy Expenditure and Neighborhood Park Design Characteristics Still Hold When Controlling for Demographic Attributes?}

The relationship of park design characteristics and seniors' total steps and energy expenditures were evaluated using multiple stepwise regression analyses (Table 8). We included age, gender, BMI, family income, health condition, and visit purpose as control variables. The multiple stepwise regression models indicated that seniors' walking step was negatively associated with senior age $(\beta=-0.164, p=0.011)$, but positively associated with natural area $(\beta=0.158, p=0.015)$ and the presence of outdoor fitness equipment $(\beta=0.149, p=0.021)$ in the park. These three factors explained 6.4\% $(p=0.002)$ of the variance in step counts in the parks. Seniors' energy expenditure was positively related to BMI $(\beta=0.241, p=$ 0.001 ), household monthly income between 5,000 and 10,000 $(\beta=0.160, p=0.024)$ and the presence of outdoor fitness equipment $(\beta=0.161, p=0.024)$ in the park, these three factors explained $9.9 \%$ of the variance $(p=0.000)$ in senior energy expenditure.

\section{DISCUSSION}

This study examined the relationships between neighborhood park design characteristics and seniors' total steps and energy expenditure in the park, using both objective and self-reported measures. We sampled 15 different parks to enhance the generalizability of the results.

\section{Seniors' Age, Household Monthly Income, and Physical Activity}

The results indicated that younger seniors walked more in the park, and seniors with a household monthly income between 5,000 and 10,000 have larger energy expenditure than those with a monthly income $<3,000 \mathrm{CNY}$. Existing research indicates that the young elderly tend to engage in more physical activity than the old elderly in daily life (53), and our findings suggest that this difference existed in park visits. Human skeletal muscle atrophies with age (54), and seniors in the 50-59 age have a better physical function than those in the 60-69 and 70-79 age groups (55). Therefore, young seniors are expected to walk more in the park. The needs of seniors in different decades and with different physical capabilities should be considered in urban park design and management. Seniors with higher incomes are more likely to participate in health promotion programs (56), report better health (57), have lower body mass index, and engage in more moderate and vigorous physical activity (58). That might explain our findings that compared to seniors with a household monthly income $<3,000 \mathrm{CNY}$, seniors with a household monthly income between 5,000 and 10,000 CNY expend more energy in the park. On the other hand, urban park provides free settings for seniors with low income to engage in physical activity, efforts are needed to encourage those seniors to actively use urban parks.

\section{Park Size, Natural Area, and Seniors' Walking}

Our findings suggest that seniors in larger neighborhood parks walk more. However, existing research with adults indicates that park size is not associated with the chance whether a park is used for physical activity (17), and features rather than park size is more important for park-based physical activity (4). One possible explanation is that previous studies used binary measures of physical activity, while our study measured walking steps and energy expenditure using continuous variables, which allows for quantitative comparisons between parks. More time spent in a park has been shown to correlate with higher levels of physical activity (59). Larger parks provide more area to explore and may encourage seniors to stay and walk for longer periods. We also found that larger natural area was associated with more walking steps. The health benefits of walking in natural areas have long been recognized (60). Nature is important to seniors (61), and can help seniors release stress (62). Compared to other adults, seniors have a stronger motivation to walk in natural environment (8). Larger natural area may contribute to a better mood and attracted seniors to stay longer and walk more. The findings suggest that we can provide larger natural area to encourage seniors' walking in the park.

\section{Trail Length and Seniors Walking}

We found total trail length is related to seniors' total steps in the park. Existing research suggests that parks with tracks draw more seniors (4). A study in Missouri finds that users of a trail longer than 0.25 mile are more likely to report an increase in physical activity (63). Trail in the park is where seniors 
TABLE 8 | Total step, energy expenditure, and park design characteristics and senior demographic attributes (stepwise model).

\begin{tabular}{|c|c|c|c|c|c|c|}
\hline Variables & Coef. (B) & $S E$ & St. Coef. $(\beta)$ & Sig. & VIF & Overall model \\
\hline \multicolumn{7}{|l|}{ Total step } \\
\hline (Constant) & 3.592 & 0.213 & & 0.000 & & $R^{2}=0.064$ \\
\hline Age & -0.008 & 0.003 & -0.164 & 0.011 & 1.005 & Sig. $=0.002$ \\
\hline Total natural area & $4.889 E-6$ & 0.000 & 0.158 & 0.015 & 1.017 & \\
\hline $\begin{array}{l}\text { Presence of outdoor } \\
\text { fitness equipment }\end{array}$ & 0.105 & 0.045 & 0.149 & 0.021 & 1.015 & \\
\hline \multicolumn{7}{|l|}{ Energy expenditure } \\
\hline & 1.465 & 0.162 & & 0.000 & & \\
\hline $\mathrm{BMI}$ & 0.023 & 0.007 & 0.241 & 0.001 & 1.038 & \\
\hline $\begin{array}{l}\text { Household monthly } \\
\text { income between } 5,000 \\
\text { and } 10,000\end{array}$ & 0.089 & 0.039 & 0.160 & 0.024 & 1.009 & $\begin{array}{l}R^{2}=0.099 \\
\text { Sig. }=0.000\end{array}$ \\
\hline $\begin{array}{l}\text { Presence of outdoor } \\
\text { fitness equipment }\end{array}$ & 0.090 & 0.040 & 0.161 & 0.024 & 1.035 & \\
\hline
\end{tabular}

Total step and energy expenditure are log-transformed.

walking on, and longer trail can provide more opportunities for seniors to walk thus may facilitate seniors walking. In parks of limited area, designers can distribute longer trails to facilitate senior walking; further investigation is needed to explore how the characteristics of park trails may facilitate walking by seniors (64).

\section{Outdoor Fitness Equipment and Seniors' Physical Activity}

We found that the presence of outdoor fitness equipment was associated with total steps and energy expenditure of seniors. Fitness equipment can accommodate a variety of fitness goals, and their presence provides opportunities for physical activity beyond walking. Existing studies reported that outdoor fitness equipment in parks attracts senior users $(49,50)$, and seniors use this equipment with the primary motivation of exercising and improving health (7). Compared to other adults, seniors have less access to walking trails and indoor gyms (63). In contrast, outdoor fitness equipment can provide seniors with important exercise opportunities (50). Landscape architects can provide outdoor fitness equipment in urban parks to facilitate the physical activity of senior visitors, and how seniors use outdoor fitness equipment should be further explored.

\section{Limitations}

The present study has some limitations that should be considered. The parks included in the study were neighborhood parks with areas of $<10 \mathrm{ha}$, and thus the results may not be applicable to larger parks such as city parks, regional parks or natural reserves. Although we included 15 parks to ensure the representativeness of the sites, all are located in Shanghai, China. The patterns of park features and park use may differ in less-dense urban areas, in suburban and rural locations, and in other cultures. Additionally, we used a convenient sample of seniors visiting the parks who volunteered to participate in the study. It is uncertain whether this population group displayed characteristics that may influence the physical activity data systematically. Third, only step counts were measured, and only pedometers were used for measurement. Future studies should consider combining pedometers, accelerometers, heartrate monitors, armbands, or multi-sensor devices for more accurate estimates of activity intensity, activity duration, and energy expenditure.

\section{CONCLUSION}

This study aimed to investigate the associations between neighborhood park design characteristics and seniors' walking and energy expenditure during park visits. The results indicated that park area, total trail length, and total natural area of the park were positive predictors of more walking. The presence of outdoor fitness equipment also contributed to more walking and energy expenditure. In addition, demographic and socioeconomic factors, as well as BMI are related to seniors' activities in parks. For example, senior's total step count was negatively associated with age; and their energy expenditure was positively related to BMI. More energy was also expended by seniors with a monthly household income between 5,000 and 10,000 CNY as compared to those with a monthly household income of $<3,000 \mathrm{CNY}$. These findings can be used to guide park design and management to promote walking and active recreation in parks. For instance, planners and designers can include more natural areas and less impervious areas, create longer trails, and provide more outdoor fitness equipment in parks, especially in parks that are located in communities that demonstrate greater inactivity and obesity. Park use patterns and the needs of seniors with diverse demographic attributes should 
also be considered and addressed in future park design and management practice.

\section{DATA AVAILABILITY STATEMENT}

The raw data can not be shared because sensitive location information is asked to be reserved by IRB.

\section{ETHICS STATEMENT}

Our study has been approved by the Institutional Review Board of Tongji University and we confirm that the

\section{REFERENCES}

1. Chodzko-Zajko W, Schwingel A, Chae Hee P. Successful aging: the role of physical activity. Am J Lifestyle Med. (2008) 3:20-8. doi: $10.1177 / 1559827608325456$

2. DHHS. Healthy People 2010: Understanding and Improving Health second. Atlanta,GA: U.S. Department of Health and Human Services, Centers for Disease Control and Prevention (2000).

3. Cohen DA, Ashwood JS, Scott MM, Overton A, Evenson KR, Staten LK, et al. Public parks and physical activity among adolescent girls. Pediatrics. (2006) 118:E1381-9. doi: 10.1542/peds.2006-1226

4. Cohen DA, McKenzie TL, Sehgal A, Williamson S, Golinelli D, Lurie N. Contribution of public parks to physical activity. Am J Public Health. (2007) 97:509-14. doi: 10.2105/AJPH.2005.072447

5. Evenson KR, Wen F, Hillier A, Cohen DA. Assessing the contribution of parks to physical activity using global positioning system and accelerometry. Med Sci Sports Exerc. (2013) 45:1981-7. doi: 10.1249/MSS.0b013e318293330e

6. Giles-Corti B, Broomhall MH, Knuiman M, Collins C, Douglas K, Ng K, et al. Increasing walking: How important is distance to, attractiveness, and size of public open space? Active Living Res. (2005) 28(2 Suppl. 2):169-76. doi: 10.1016/j.amepre.2004.10.018

7. Chow HW. Outdoor fitness equipment in parks: a qualitative study from older adults' perceptions. BMC Public Health. (2013) 13:1216. doi: 10.1186/1471-2458-13-1216

8. Jorgensen A, Anthopoulou A. Enjoyment and fear in urban woodlands Does age make a difference? Urban Forest Urban Green. (2007) 6:267-78. doi: 10.1016/j.ufug.2007.05.004

9. Wen C, Albert C, Von Haaren C. The elderly in green spaces: Exploring requirements and preferences concerning nature-based recreation. Sustain Cities Soc. (2018) 38:582-93. doi: 10.1016/j.scs.2018.01.023

10. Payne L, Orsega-Smith E, Roy M, Godbey G. Local park use and personal health among older adults: an exploratory study. J Park Recreat Admin. (2005) 23:1-20.Available online at: https://js.sagamorepub.com/jpra/article/ view/1433

11. Alves S, Aspinall PA, Ward Thompson C, Sugiyama T, Brice R, Vickers A. Preferences of older people for environmental attributes of local parks: The use of choice-based conjoint analysis. Facilities. (2008) 26:433-53. doi: 10.1108/02632770810895705

12. Aspinall PA, Thompson CW, Alves S, Sugiyama T, Brice R, Vickers A. Preference and relative importance for environmental attributes of neighbourhood open space in older people. Environ Plann B Plann Des. (2010) 37:1022-39. doi: 10.1068/b36024

13. Li D, Zhai Y, Xiao Y, Newman G, Wang D. Subtypes of park use and self-reported psychological benefits among older adults: a multilevel latent class analysis approach. Landsc Urb Plann. (2019) 190:103605. doi: 10.1016/j.landurbplan.2019.103605

14. Loukaitou-Sideris A, Levy-Storms L, Chen L, Brozen M. Parks for an aging population: needs and preferences of low-income seniors in Los Angeles. $J$ Am Plann Assoc. (2016) 82:236-51. doi: 10.1080/01944363.2016.1163238 patients/participants provided their written informed consent to participate in this study.

\section{AUTHOR CONTRIBUTIONS}

All authors listed have made a substantial, direct and intellectual contribution to the work, and approved it for publication.

\section{FUNDING}

This study was supported by National Science Foundation of China (No. 51508390) and the Fundamental Research Funds for the Central Universities of China (No. 22120180069).

15. Coombes E, Jones AP, Hillsdon M. The relationship of physical activity and overweight to objectively measured green space accessibility and use. Soc Sci Med. (2010) 70:816-22. doi: 10.1016/j.socscimed.2009. 11.020

16. Gong Y, Gallacher J, Palmer S, Fone D. Neighbourhood green space, physical function and participation in physical activities among elderly men: the Caerphilly Prospective study. Int J Behav Nutr Phys Act. (2014) 11:40. doi: 10.1186/1479-5868-11-40

17. Kaczynski AT, Potwarka LR, Saelens BE. Association of park size, distance, and features with physical activity in neighborhood parks. Am J Public Health. (2008) 98:1451-6. doi: 10.2105/AJPH.2007.129064

18. Floyd MF, Spengler JO, Maddock JE, Gobster PH, Suau LJ. Park-based physical activity in diverse communities of two US cities - An observational study. Am J Prev Med. (2008) 34:299-305. doi: 10.1016/j.amepre.2008.01.009

19. Kira K. 'The only place to go and be in the city': women talk about exercise, being outdoors, and the meanings of a large urban park. Health Place. (2006) 12:631-43. doi: 10.1016/j.healthplace.2005.08.015

20. Reed AJ, Cheryl-Anne A, Princess W, Katherine S, Sandra H, Holly H. A descriptive examination of the most frequently used activity settings in 25 community parks using direct observation. J Phys Act Health. (2008) 5:183-95. doi: 10.1123/jpah.5.s1.s183

21. Akpinar A. How is quality of urban green spaces associated with physical activity and health? Urban Forest Urban Green. (2016) 16:76-83. doi: 10.1016/j.ufug.2016.01.011

22. Elliott LR, White MP, Taylor AH, Herbert S. Energy expenditure on recreational visits to different natural environments. Soc Sci Med. (2015) 139:53-60. doi: 10.1016/j.socscimed.2015.06.038

23. Kaczynski AT, Besenyi GM, Stanis SAW, Koohsari MJ, Oestman KB, Bergstrom R, et al. Are park proximity and park features related to park use and park-based physical activity among adults? Variations by multiple socio-demographic characteristics. Int J Behav Nutr Phys Act. (2014) 11:146. doi: 10.1186/s12966-014-0146-4

24. Koohsari MJ, Kaczynski AT, McCormack GR, Sugiyama T. Using space syntax to assess the built environment for physical activity: applications to research on parks and public open spaces. Leisure Sci. (2014) 36:206-16. doi: 10.1080/01490400.2013.856722

25. Evenson KR, Jones SA, Holliday KM, Cohen DA, McKenzie TL. Park characteristics, use, and physical activity: A review of studies using SOPARC (System for Observing Play and Recreation in Communities). Prev Med. (2016) 86:153-66. doi: 10.1016/j.ypmed.2016.02.029

26. Lindberg M, Schipperijn J. Active use of urban park facilities Expectations versus reality. Urban Forest Urban Green. (2015) 14:909-18. doi: 10.1016/j.ufug.2015.08.007

27. Tudor-Locke C, Williams JE, Reis JP, Pluto D. Utility of pedometers for assessing physical activity. Sports Med. (2002) 32:795-808. doi: 10.2165/00007256-200232120-00004

28. Tudor-Locke C, Williams JE, Reis JP, Pluto D. Utility of pedometers for assessing physical activity. Sports Med. (2004) 34:281-91. doi: 10.2165/00007256-200434050-00001 
29. Zhai Y, Baran PK. Urban park pathway design characteristics and senior walking behavior. Urban Forest Urban Green. (2017) 21:60-73. doi: 10.1016/j.ufug.2016.10.012

30. Akpinar A, Cankurt M. How are characteristics of urban green space related to levels of physical activity: examining the links. Indoor Built Environ. (2017) 26:1091-101. doi: 10.1177/1420326X16663289

31. Ward Thompson C. Activity, exercise and the planning and design of outdoor spaces. J Environ Psychol. (2013) 34:79-96. doi: 10.1016/j.jenvp.2013.01.003

32. Shanghai Greening Administration Bureau. Shanghai Greening and Landscape Yearbook 2016. Shanghai: Shanghai Culture Express (2016).

33. Shanghai Municpal Statistics Bureau. Shanghai Statistical Yearbook 2017. Beijing: China Statistics Press (2017). Available online at: http://www.statssh.gov.cn/data/toTjnj.xhtml?y=2015 (accessed September 3, 2017).

34. Xin L, Guo Y. Evolution of permanent population and employed population in Shanghai central districts. In: Paper Presented at the Chinese Urban Planning 2014 Annual Conference Proceeding. Haiko.

35. Zhang Q, Xia L, Qiao P, Yang, W. Development dynamic, distribution pattern and scale characters of the parks system in Shanghai. Chin Landsc Architect. (2001) 1:58-61. doi: 10.3969/j.issn.1000-6664.2001.01.018

36. Zhai $\mathrm{Y}, \mathrm{Wu} \mathrm{H}$, Fan $\mathrm{H}$, Wang D. Using mobile signaling data to exam urban park service radius in Shanghai: methods and limitations. Comp Environ Urban Syst. (2018) 71:27-40. doi: 10.1016/j.compenvurbsys.2018.03.011

37. Cruz J, Brooks D, Marques A. Accuracy of piezoelectric pedometer and accelerometer step counts. J Sports Med Phys Fitness. (2016) 57:426-33. doi: 10.23736/S0022-4707.16.06177-X

38. Bassett DR Jr. Validity and reliability issues in objective monitoring of physical activity. Res Q Exerc Sport. (2000) 71:30-6. doi: 10.1080/02701367.2000.11082783

39. Webber SC, Magill SM, Schafer JL, Wilson KCS. GT3X+ accelerometer, yamax pedometer, and SC-StepMX pedometer step count accuracy in community-dwelling older adults. J Aging Phys Act. (2014) 22:334-41. doi: 10.1123/JAPA.2013-0002

40. Beevi FH, Miranda J, Pedersen CF, Wagner S. An evaluation of commercial pedometers for monitoring slow walking speed populations. Telemed $e$ Health. (2016) 22:441-9. doi: 10.1089/tmj.2015.0120

41. Bohannon RW, Andrews AW, Thomas MW. Walking speed: reference values and correlates for older adults. J Orthopaed Sports Phys Ther. (1996) 24:86-90. doi: 10.2519/jospt.1996.24.2.86

42. Brown G. A theory of urban park geography. J Leis Res. (2008) 40:589.

43. Baran KP, Smith WR, Moore RC, Floyd MF, Bocarro JN, Cosco NG, et al. Park Use among youth and adults: examination of individual, social, and urban form factors. Environ Behav. (2013) 46. doi: 10.1177/0013916512470134

44. Bratman GN, Daily GC, Levy BJ, Gross JJ. The benefits of nature experience: Improved affect and cognition. Landsc Urban Plan. (2015) 138:41-50. doi: 10.1016/j.landurbplan.2015.02.005

45. Hartig T, Evans GW, Jamner LD, Davis DS, Gärling T. Tracking restoration in natural and urban field settings. J Environ Psychol. (2003) 23:109-23. doi: 10.1016/S0272-4944(02)00109-3

46. Li D, Deal B, Zhou X, Slavenas M, Sullivan WC. Moving beyond the neighborhood: Daily exposure to nature and adolescents' mood. Landsc Urban Plan. (2018) 173:33-43. doi: 10.1016/j.landurbplan.2018.01.009

47. Ulrich RS. Natural versus urban scenes: some psychophysiological effects. Environ. Behav. (1981) 13:523-56. doi: 10.1177/0013916581135001

48. Whitaker B, Browne K. Parks for People. New York, NY: Schocken Books (1973).

49. Chow HW, Mowen AJ, Wu GL. Who is using outdoor fitness equipment and how? The Case of Xihu Park. Int J Environ Res Public Health. (2017) 14:448. doi: 10.3390/ijerph14040448
50. Stride V, Cranney L, Scott A, Hua M. Outdoor gyms and older adults acceptability, enablers and barriers: a survey of park users. Health Promot J Aust. (2017) 28:243-6. doi: 10.1071/HE16075

51. Cranney L, Phongsavan P, Kariuki M, Stride V, Scott A, Hua M, et al. Impact of an outdoor gym on park users' physical activity: A natural experiment. Health \& Place. (2016) 37:26-34. doi: 10.1016/j.healthplace.2015.11.002

52. Shores KA, West ST. The relationship between built park environments and physical activity in four park locations. J Public Health Manag Pract. (2008) 14:e9-16. doi: 10.1097/01.PHH.0000316495.01153.b0

53. Milanovic Z, Pantelic S, Trajkovic N, Sporis G, Kostic R, James N. Age-related decrease in physical activity and functional fitness among elderly men and women. Clin Interven Aging. (2013) 8:549. doi: 10.2147/CIA.S44112

54. Faulkner JA, Larkin LM, Claflin DR, Brooks SV. Age-related changes in the structure and function of skeletal muscles. Clin Exp Pharmacol Physiol. (2007) 34:1091-6. doi: 10.1111/j.1440-1681.2007.04752.x

55. Tsubaki A, Kubo M, Kobayashi R, Jigami H, Takahashi HE. Age-related changes in physical function in community-dwelling people aged 50-79 years. J Phys Ther Sci. (2010) 22:23-7. doi: 10.1589/jpts.22.23

56. Wagner EH, Grothaus LC, Hecht JA, Lacroix AZ. Factors associated with participation in a senior health promotion program. Gerontologist. (1991) 31:598-602. doi: 10.1093/geront/31.5.598

57. Wagnild G. Resilience and successful aging. Comparison among low and high income older adults. J Gerontol Nurs. (2003) 29:42. doi: 10.3928/0098-9134-20031201-09

58. King AC, Sallis JF, Frank LD, Saelens BE, Cain K, Conway TL, et al. Aging in neighborhoods differing in walkability and income: associations with physical activity and obesity in older adults. Soc Sci Med. (2011) 73:1525-33. doi: 10.1016/j.socscimed.2011.08.032

59. Dewulf B, Neutens T, Van Dyck D, de Bourdeaudhuij I, Broekx S, Beckx $\mathrm{C}$, et al. Associations between time spent in green areas and physical activity among late middle-aged adults. Geospatial Health. (2016) 11:225-32. doi: 10.4081/gh.2016.411

60. Carpenter M. From 'healthful exercise' to 'nature on prescription': The politics of urban green spaces and walking for health. Landsc Urb Plann. (2013) 118:120-7. doi: 10.1016/j.landurbplan.2013.02.009

61. Talbot JF, Kaplan R. The benefits of nearby nature for elderly apartment residents. Int J Aging Human Dev. (1991) 33:119-30. doi: 10.2190/XK9Q-3MDL-XYW9-9QL3

62. Rodiek S. Influence of an outdoor garden on mood and stress in older adults. J Ther Hortic. (2002) 13:13-21.

63. Brownson RC, Housemann RA, Brown DR, Jackson-Thompson J, King AC, Malone BR, et al. Promoting physical activity in rural communities Walking trail access, use, and effects. Am J Prev Med. (2000) 18:235-41. doi: 10.1016/S0749-3797(99)00165-8

64. Starnes HA, Troped PJ, Klenosky DB, Doehring AM. Trails and physical activity: a review. J Phys Act Health. (2011) 8:1160-74. doi: 10.1123 /jpah.8.8.1160

Conflict of Interest: The authors declare that the research was conducted in the absence of any commercial or financial relationships that could be construed as a potential conflict of interest.

Copyright (C) 2020 Zhai, Li, Wang and Shi. This is an open-access article distributed under the terms of the Creative Commons Attribution License (CC BY). The use, distribution or reproduction in other forums is permitted, provided the original author(s) and the copyright owner(s) are credited and that the original publication in this journal is cited, in accordance with accepted academic practice. No use, distribution or reproduction is permitted which does not comply with these terms. 